Available online on 15.02.2020 at http://jddtonline.info
Open Access to Pharmaceutical and Medical Research
unrestricted non-commercial use, provided the original work is properly cited

Open 2 Access

Research Article

\title{
Antihyperglycaemic and antioxidant activities of Crataeva adansonii DC. ssp. adansonii leaves extract on ICR mice
}

\section{Atchou Kokou 1*, Lawson-Evi Povi 1, Metowogo Kossi 1, Bakoma Batomayena 2, Eklu-Gadegbeku Kwashie 1, AkliKokou Kodjo ${ }^{1}$, Gbeassor Mensavi}

${ }^{1}$ Laboratory of Physiology-Pharmacology, Faculty of Sciences, University of Lome, Lome-Togo

${ }^{2}$ Department of Pharmacy, Faculty of Health Sciences, University of Lome, Lome-Togo

\begin{abstract}
Crataeva adansonii DC. ssp. adansonii is a medicinal plant belong to Capparidaceae family, used traditionally by Togolese to treat diabetes mellitus. The aim of this study was to evaluate the antihyperglycaemic and antioxidant activities of the plant leaves. The effect of hydroethanolic extract of $C$. adansonii ssp. adansonii leaves was assessed in vivo on blood glucose levels in fasting normal and glucose loaded hyperglycemic (oral glucose tolerance test) mice. The phytochemical screening has been done by coloring tests in chemistry. In vitro antioxidants assays had been performed by 2, 2'-azobis 2 amidinopropane dihydrochloride (AAPH) free radical scavenging assay, Ferric reducing antioxidant power (FRAP) assay, $\mathrm{Fe}^{2+}$ chelating assay and total antioxidant capacity (TAC) quantification. After 30 min glucose loading (4 g/kg), the extract 500 $\mathrm{mg} / \mathrm{kg}$ was showed a significant $(p<0.001)$ decreased of the peak of blood glucose compared to the hyperglycemic control. The two doses of extract ( 250 and $500 \mathrm{mg} / \mathrm{kg}$ ) did not act on the basic blood glucose compared to the normoglycemic control. Phytochemical screening revealed a presence of flavonoids, tannins, alkaloids and sterols. AAPH free radical scavenging activity, reducing power, Fe ${ }^{2+}$ chelating activity and total antioxidant capacity have shown dose-dependent antioxidant capacity and reducing power of extract compared to ascorbic acid and Butylated hydroxyl Toluene used as reference drug. These finding prove that $C$. adansonii ssp. adansonii leaves can be used in the treatment of diabetes mellitus and its complications related to oxidative stress and support the use of the plant in traditional medicine in diabetes treatment.
\end{abstract}

Keywords: Crataeva adansonii, antihyperglycaemic, phytochemical, antioxidant.

Article Info: Received 13 Nov 2019; $\quad$ Review Completed 04 Jan 2020; Accepted 12 Jan 2020; Available online 15 Feb 2020

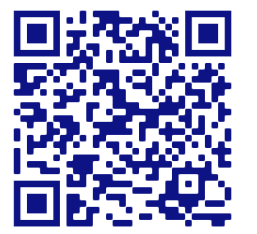

\section{Cite this article as:}

Atchou K, Lawson-Evi P, Metowogo K, Bakoma B, Eklu-Gadegbeku K, AkliKokou K, Gbeassor M, Antihyperglycaemic and antioxidant activities of Crataeva adansonii DC. ssp. adansonii leaves extract on ICR mice, Journal of Drug Delivery and Therapeutics. 2020; 10(1-s):30-38 http://dx.doi.org/10.22270/jddt.v10i1-s.3855

*Address for Correspondence:

Atchou Kokou, Laboratory of Physiology-Pharmacology, Faculty of Sciences, University of Lome, Lome-Togo

\section{INTRODUCTION}

Diabetes is a metabolic disease that is nowadays a major public health problem and has significant economic consequences in the treatment of its complications. It characterized by a high hyperglycemia and diagnosed by fasting blood glucose $\geq 126 \mathrm{mg} / \mathrm{dl}(7 \mathrm{mmol} / \mathrm{l})$ or $\geq 200$ $\mathrm{mg} / \mathrm{dL}(11.1 \mathrm{mmol} / \mathrm{l})$ after oral glucose tolerance test [1]. This high chronicle hyperglycemia result to the defect in insulin secretion, it action or both combined anomalies. Diabetes can be ranked in four types: diabetes type 1, common in children and young people (5 to $10 \%$ of cases); diabetes types 2, observed in adults (90 to $95 \%$ of cases); pregnancy diabetes which touch 3 to $20 \%$ of the pregnant women; in end others types of diabetes due to various reasons $[1,2]$. The two meanly type of diabetes mellitus result on the progressive loss of pancreatic $\beta$-cell by autoimmune processes following deficiency in insulin (type 1 diabetes) and a decreased sensitivity of insulin receptors to insulin and pancreatic $\beta$-cell dysfunction which leads to insulin resistance (type 2 diabetes). Whatever the type of diabetes, there is a hyperglycemia that untreated causes complications. The prevalence of the disease is increasing and it mainly due to the aging of population and lifestyle like sedentary and eating habits. According to the International Diabetes Federation (IDF), the prevalence of diabetes was $8.8 \%$ in 2017 and will be 9.9 in 2045 if nothing is made [2]. In the worldwide, every 6 seconds about 1 person dies of diabetes and most of them occur in low- and middle-income countries. In Africa, $4.4 \%$ of adults had diabetes and this prevalence reached $6.2 \%$ for Togo in 2017 [2].

In fact, diabetes complications can be avoided or retarded while normalizing as possible the blood glucose level, the arterial pressure and the blood cholesterol level. In conventional medicine, oral hypoglycemic agents and some insulin gave their proofs, but are not without side effects. Besides, the cost of diabetes treatment is out of the range of 
some patient. These situations bring patients to turn toward the traditional medicine for alternative care. The use of the plants in traditional medicine dates for very long and they have needed to be studied to bring the scientific proofs to their efficiency. Crataeva adansonii DC. is one of antidiabetic plant belonging to Capparidaeae family and commonly called sacred garlic pear or temple plant. In traditional pharmacopeia, the plant is used as astringent and treats affections such as urinary, renal tubules, uterine, gastrointestinal, skin, inflammatory, asthma and snakebites [3, 4]. In Togo, the plant is consumed as a legume and traditionally used to treat diseases such as abscesses, wounds, bacterial infections, rheumatism and diabetes. Previously studies have reported antimicrobial, anticancer, antiparasitic, analgesic, antioxidant, antidiabetic and antihypertension activities of $C$. adansonii [5, 6]. Despite the widespread use of C. adansonii, scientific data on its antidiabetic properties are very paucity. This study aimed to determine the antidiabetic properties of $C$. adansonii DC. ssp. adansonii and to prove its use in traditional pharmacopoeia.

\section{MATERIALS AND METHODS}

\section{Plant material}

The leave of $C$. adansonii spp. adansonii is used as plant material. It has been collected in $4^{\text {th }}$ district at Nyekonakpoe (Lome city, Togo). The plant materiel was identified at Botany and Plant Ecology Laboratory (Faculty of Science/University of Lomé) where voucher specimen was deposited in the herbarium as herbarium specimen No. 15190. The leaves of the plant were dried at $25 \pm 2{ }^{\circ} \mathrm{C}$ in safe from light for two week and then reduce in powder.

\section{Animals}

The animal material consists of ICR mice weighing $25 \pm 5 \mathrm{~g}$. They have been provided by Laboratory of Animal Physiology (Faculty of the Sciences/University of Lome) and have been kept in cages under standard environmental conditions with free access to water and food. In vivo test on mice was conducted in accordance with institutional guidelines and ethics of Laboratory of PhysiologyPharmacology of University of Lome-Togo referred as 001/2012/ CB-FDS-UL.

\section{Extraction}

C. adansonii leaves powder (400 g) was macerated in 4 liter of mixture of ethanol-water (70: 30) for $72 \mathrm{~h}$. The macerate was filtered on hydrophilic cotton and then on Wattman paper No. $\mathrm{n}^{\circ} 40$ (Ø150 mm) and evaporated to dryness at 45 ${ }^{\circ} \mathrm{C}$ using a rotary evaporator under vacuum (Büchi Rotavapor R210, Germany). The resulting dry extract was collected in a sterile glass vial and placed in a desiccator for $24 \mathrm{~h}$ and then stored in the refrigerator at $4-8{ }^{\circ} \mathrm{C}$.

\section{Effect of extract on mice hyperglycemic}

Oral glucose tolerance test (OGTT) was used to induce hyperglycemia. Mice were fasted $(7 \mathrm{~h})$ and blood glucose was measured before to administrate all solutions. Animals were divided into 5 groups of 5 mice each. Hyperglycemic control received distilled water $(5 \mathrm{~mL} / \mathrm{kg})$, treated groups received extracts 250 and $500 \mathrm{mg} / \mathrm{kg}$ and reference groups received metformin $100 \mathrm{mg} / \mathrm{kg}$ by gavage 30 minutes before glucose overload ( $4 \mathrm{~g} / \mathrm{kg}$ body weight) at rate of $5 \mathrm{~mL} / \mathrm{kg}$. Normoglycemic controls received only distilled water (no glucose overload). Blood glucose levels were measured from the tail vein blood of mice using One Touch Ultra Glucometer (USA) during $180 \mathrm{~min}(0 \mathrm{~min}$ before and $30 \mathrm{~min}, 60 \mathrm{~min}, 120$ min, $180 \mathrm{~min}$ after glucose loading).

\section{Effect of extract on mice basic blood glucose}

Mice were divided into 4 groups (5 mice each). Normoglycemic controls group received only distilled water ( $5 \mathrm{~mL} / \mathrm{kg}$ body weight), treated groups received extract (250 and $500 \mathrm{mg} / \mathrm{mL}$ ) and reference groups received metformin $(100 \mathrm{mg} / \mathrm{mL})$. Blood glucose levels were measured at the tail vein on $180 \mathrm{~min}(0 \mathrm{~min}$ before and 30 min, $60 \mathrm{~min}, 90 \mathrm{~min}, 120 \mathrm{~min}, 180 \mathrm{~min}$ after administration the solutions by gavage).

\section{Phytochemical screening}

Qualitative phytochemicals analyses were sought in the extracts by coloring tests in chemistry $[7,8]$. The presence of alkaloids was performed by Mayer and Bouchardat reaction; tannins by $\mathrm{FeCl}_{3} 2 \%$ reaction; flavonoids by $\mathrm{NaOH} \mathrm{N} / 10$ and $\mathrm{FeCl}_{3}$ reaction; reducing compounds by Molish, KellerKilliani and Fehling reaction; saponins by foams test; in end sterols and terpenes by Liebermann-Buchard reacion.

\section{Total phenols and tannins contents}

Principle: All the phenolic compounds of the extract were oxidized by the Folin-Ciocalteu reagent (a mixture of phosphotungstic acid $\left(\mathrm{H}_{3} \mathrm{PW}_{12} \mathrm{O}_{40}\right)$ and phosphomolybdic acid $\left.\left(\mathrm{H}_{3} \mathrm{PMo}_{12} \mathrm{O}_{40}\right)\right)$ which is reduced during the oxidation of the phenols in a mixture of blue oxides of tungsten $\left(\mathrm{W}_{40} \mathrm{O}_{23}\right)$ and molybdenum $\left(\mathrm{Mo}_{8} \mathrm{O}_{23}\right)$. The resulting blue color absorbs around $750 \mathrm{~nm}$. Fixing tannins by polyvinylpolypyrrolidone (PVPP) made it possible to deduce their quantity of the total phenols after a second dosage $[9,10]$. The test was performed by adding $200 \mu \mathrm{L}$ of Folin-C $10 \%$ reagent to $200 \mu \mathrm{L}$ of extract (1 mg/mL in methanol 95\%) or to $200 \mu \mathrm{L}$ of supernatant of PVPP-fixed extract solution (previously fixed tannins by adding $500 \mu \mathrm{L}$ of extract to $10 \mathrm{mg}$ of PVPP dissolve in $500 \mu \mathrm{L}$ of methanol $95 \%$ ) and incubated at $28 \pm 2{ }^{\circ} \mathrm{C}$ for $15 \mathrm{~min}$. After incubation, $800 \mu \mathrm{L}$ of sodium carbonate solution $(700$ $\mathrm{mM}$ ) were added and absorbance was measured at $735 \mathrm{~nm}$ against blank. Gallic acid (GA) $(0 ; 25 ; 50 ; 100 ; 150 ; 100$ $\mu \mathrm{g} / \mathrm{mL}$ ) was used as standard to generate the calibration curve. Tannins have been subtracted from total phenols by differentiating optical densities (OD): $\mathrm{OD}_{\text {tanins }}=0 \mathrm{D}_{\text {extract }}$ OD extract+PVP. Total phenol and tannins were expressed as mg equivalence of $\mathrm{GA} / \mathrm{g}$ of extract.

\section{Total flavonoids content}

The flavonoids contained in the extract were determined by the aluminum chloride $\left(\mathrm{AlCl}_{3}\right)$ method [9, 11]. In principle, flavonoids form with alumina chloride a flavonoidaluminum complex that absorbs at $440 \mathrm{~nm}$. The test was performed by adding $2 \mathrm{~mL}$ of $\mathrm{AlCl}_{3}(20 \mathrm{mg} / \mathrm{mL}$ in distilled water) and $6 \mathrm{~mL}$ of sodium acetate $(50 \mathrm{mg} / \mathrm{mL}$ in distilled water) to $2 \mathrm{~mL}$ of extract ( $1 \mathrm{mg} / \mathrm{mL}$ in methanol). Mixed and incubated at laboratory temperature for $2 \mathrm{~h} 30 \mathrm{~min}$. The absorbance was measured at $440 \mathrm{~nm}$ against blank. Rutin (1; $5 ; 25 ; 50 ; 100 \mu \mathrm{g} / \mathrm{mL}$ ) was used as standard to generate the calibration curve. The total flavonoids were expressed in mg of equivalence of Rutin/g of extract.

\section{In vitro antioxidant assays}

\section{Total antioxidant capacity (TAC) assay}

The principle is based on the reduction of molybdenum ion Mo $(+6)$ in Mo $(+5)$ by the extract and the subsequent formation of the phosphate-Mo $(+5)$ green complex at acidic $\mathrm{pH}$. The test was performed by adding $3 \mathrm{~mL}$ of reagent (Sulfuric acid $0.6 \mathrm{M}$, sodium phosphate $28 \mathrm{mM}$ and ammonium molybdate $4 \mathrm{mM}$ ) to $0.3 \mathrm{~mL}$ of extract (1 $\mathrm{mg} / \mathrm{mL}$ ) prepared in methanol. It was incubated at $95{ }^{\circ} \mathrm{C}$ for $90 \mathrm{~min}$ and then brought back to laboratory temperature. Absorbance was measured at $695 \mathrm{~nm}$ against blank [12]. For 


\section{Atchou et al}

the blank, extract was replaced by methanol. Ascorbic acid $(31.25 ; 62.5 ; 125 ; 250 \mu \mathrm{g} / \mathrm{mL})$ was used as standard to generate the calibration curve. The total antioxidant capacity was expressed as mg equivalence of ascorbic acid/g of extract.

\section{Ferric reducing antioxidant power (FRAP)}

The principle is based on the reaction of reducing compounds with ferric potassium cyanide $\left(\mathrm{Fe}^{3+}\right)$ to form ferrous potassium cyanide $\left(\mathrm{Fe}^{2+}\right)$ which reacts with ferric chloride to form ferrous-ferric complex that has a maximum absorbance at $700 \mathrm{~nm}$. The test was performed by mixing $2.5 \mathrm{~mL}$ of phosphate buffer $(0.2 \mathrm{M}$; pH 6.6$)$ and $2.5 \mathrm{~mL}$ of potassium ferricyanide (1\%) with $0.5 \mathrm{~mL}$ of extract (50; 100; 200; 400; $800 \mu \mathrm{g} / \mathrm{mL}$ ) prepared in methanol. The mixture was incubated at $50{ }^{\circ} \mathrm{C}$ for $20 \mathrm{~min}$ and then, $2.5 \mathrm{~mL}$ of trichloroacetic acid $10 \%$ was added and centrifuged at 3000 rpm for $10 \mathrm{~min}$. To $2.5 \mathrm{~mL}$ of supernatant, $2.5 \mathrm{~mL}$ of distilled water and $0.5 \mathrm{~mL}$ of iron chloride $0.1 \%$ were added successively. Ascorbic acid and Butylated hydroxyl Toluene (BHT) was used as reference antioxidant. Absorbance was measured at $700 \mathrm{~nm}[9,13]$. The intensity of the absorbance indicates the intensity of the reducing power.

\section{$A A P H$ free radical scavenging assay}

In the principle, the decomposition of 2, 2'-azobis 2 amidinopropane dihydrochloride (AAPH) generates free radicals at constant speed that attack the red blood cells membrane. When there is no more endogenous antioxidant, the membrane of the red blood cells burst and the hemoglobin is found in the supernatant. The addition in the medium of molecules or extracts with antioxidant properties delays the onset of hemolysis. The test was performed by bringing $250 \mu \mathrm{L}$ of red blood cells (washed in PBS) and 250 $\mu \mathrm{L}$ of AAPH in contact of $250 \mu \mathrm{L}$ of extract $(50 ; 100 ; 150$; 200; $250 \mu \mathrm{g} / \mathrm{mL}$ ). After incubated for $3 \mathrm{~h}$, at $37^{\circ} \mathrm{C}, 4 \mathrm{~mL}$ of PBS (phosphate buffered solution) was added and then centrifuged at $1000 \mathrm{~g}$ for $10 \mathrm{~min}$. Absorbance was measured at $540 \mathrm{~nm}[9,14]$. For control extract was replaced by PBS. Ascorbic acid was used as reference antioxidant. Inhibition

$$
\%=\left(\frac{\mathrm{OD} \text { control }-\mathrm{OD} \text { sample }}{\mathrm{OD} \text { control }}\right) \times 100 \text {. }
$$

\section{Metal $\left(\mathrm{Fe}^{2+}\right)$ chelating activity assay}

The method is based on the ability of extracts to chelate $\mathrm{Fe}^{2+}$ ions [15]. The test was performed by adding $50 \mu \mathrm{L}$ of $\mathrm{FeCl}_{2}(2$ $\mathrm{mmol} / \mathrm{l})$ to $0.5 \mathrm{~mL}$ of extract $(50 ; 100 ; 150 ; 200 ; 250$ $\mu \mathrm{g} / \mathrm{mL}$ ). The reaction was initiated with $200 \mu \mathrm{L}$ of ferrozine ( $5 \mathrm{mmol} / \mathrm{l})$ and then stirred vigorously. After incubated 10 min at room temperature $\left(28 \pm 2{ }^{\circ} \mathrm{C}\right)$, the absorbance was
Journal of Drug Delivery \& Therapeutics. 2020; 10(1-s):30-38

measured at $562 \mathrm{~nm}$. Ethylenediaminetetraacetic acid (EDTA) was used as reference antioxidant. For control, extract was replaced by methanol.

Ferrozine- $\mathrm{Fe}^{2+}$ inhibition $\%=\left(\frac{\mathrm{OD} \text { control }-\mathrm{OD} \text { sample }}{\mathrm{OD} \text { control }}\right) \times 100$.

\section{Statistical analyzes}

Data were expressed as mean \pm SEM (standard error of the mean) using the GraphPad Prism 6 software. Statistical differences between treated groups and controls were determined by 2 ways ANOVA and considered significant for $p<0.05$.

\section{RESULTS AND DISCUSSION \\ RESULTS}

Effect of extract on mice oral glucose tolerance test (OGTT)

After 30 min glucose overload, the blood glucose increased significantly to reach a peak before decreasing. This increase of glycaemia was significant at t30 ( $p<0.001)$, t60 ( $p<$ $0.001)$, and $120(p<0.05)$. During this time, blood glucose levels increased to $129.98 \%$ (from $93.400 \pm 7.082$ to $214.800 \pm 7.813 \mathrm{mg} / \mathrm{dL}$ ) at $\mathrm{t} 30$ before remained nearly to the normal around 180 min (Figure 1A). The area under the curve (AUC) of glucose tolerance, which measured the total amount of available glucose in the blood, also showed a significant $(p<0.001)$ increase $(72.04 \%)$ in blood glucose levels in OGTT mice $\left(\mathrm{AUC}_{\mathrm{HC}}=25749 \mathrm{~min} \cdot \mathrm{mg} / \mathrm{dL}\right)$ when compared to normoglycemic control $\left(\mathrm{AUC}_{\mathrm{NC}}=14967\right.$ min.mg/dL) (Figure 1B).

The administration of extract $30 \mathrm{~min}$ prior to OGTT, significantly prevented the rise in blood glucose in the fasted mice when compared to the hyperglycemic controls. The extract $250 \mathrm{mg} / \mathrm{kg}$ body weight did not cause a significant decrease in blood glucose during the $180 \mathrm{~min}$. By vs, the extract $500 \mathrm{mg} / \mathrm{kg}$ body weight caused a significant decrease in blood glucose over the same time. This decrease was $32.31 \%(p<0.001)$ at t30; $55.86 \%(p<0.001)$ at t60 and $42.72 \%(p<0.01)$ at 120 . At t180, this decrease is no longer significant. Metformin $100 \mathrm{mg} / \mathrm{kg}$, used as a reference drug, significantly reduced blood glucose at time t30 (28.68\%; $p<$ 0.001 ) and t60 (26.39\%; $p<0.01$ ) (Figure 1A). AUCs of glucose tolerance showed a significant decrease for both doses of extract and Metformin. Blood glucose decreased to $14.67 \%(p<0.05)$ for extract $250 \mathrm{mg} / \mathrm{kg}$; to $40.77 \%(p<$ 0.001 ) for extract $500 \mathrm{mg} / \mathrm{kg}$ and to $20.85 \%(p<0.01)$ for metformin $100 \mathrm{mg} / \mathrm{kg}$ (Figure 1B). 


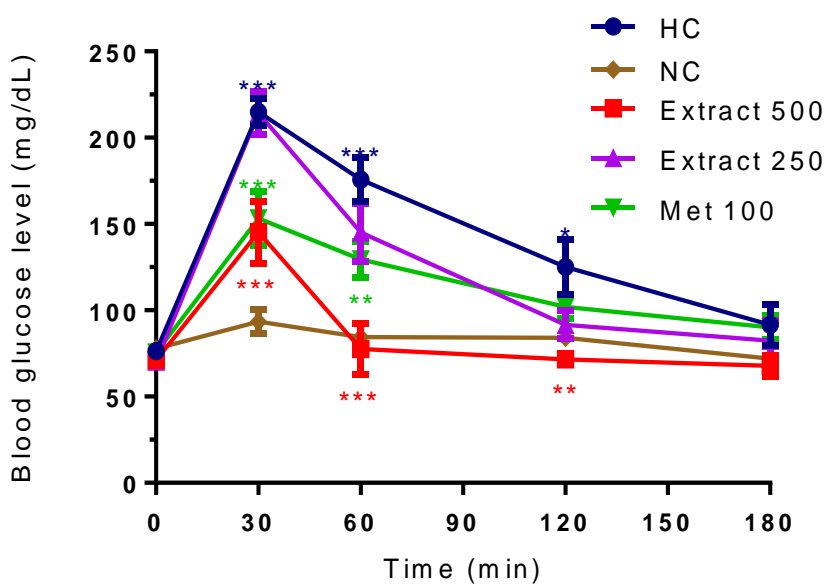

A

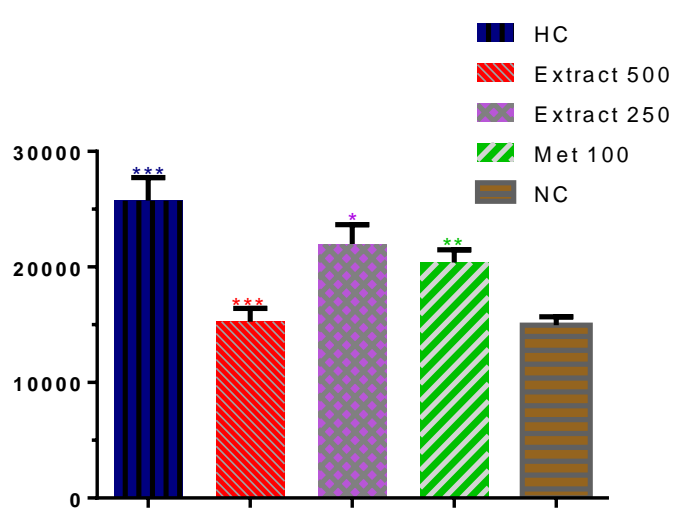

B

Figure 1: Effects of $C$. adansonii extract on oral glucose tolerance (A = Blood glucose level vs time, $\mathrm{B}=$ Area under the curve (AUC) of blood glucose) Blood glucose was measured for $180 \mathrm{~min}$ at different time: $\mathrm{t} 0=0 \mathrm{~min}$, corresponds to basal blood glucose level of the fasted mice and t30; t60; t120; 1180 correspond to 30; 60; 120 and $180 \mathrm{~min}$ after glucose overload. HC = hyperglycemic controls; $\mathrm{NC}=$ Normoglycemic controls; Extract $250,500=$ extract 250 and $500 \mathrm{mg} / \mathrm{kg}$; Met $100=$ metformin $100 \mathrm{mg} / \mathrm{kg}$. The values are expressed in means \pm SEM. $* \mathrm{p}<0.05 ; * * \mathrm{p}<0.01$; $* * \mathrm{p}<0.001$ compared to $\mathrm{HC}$ and NC. $\mathrm{n}=5$.

\section{Effect of extract on basal blood glucose}

The administration of extract at doses of 500 and $250 \mathrm{mg} / \mathrm{kg}$ did not result in a significant decrease in the basal glycaemia of the mice when compared to the normoglycemic control whose blood glucose level oscillated around the initial value $(77.800 \pm 4.176 \mathrm{mg} / \mathrm{dL})$ during the $180 \mathrm{~min}$. The reference drug, metformin $100 \mathrm{mg} / \mathrm{kg}$, did not significantly decrease basal blood glucose (Figure 2A). AUCs also remained without significant difference (Figure 2B).
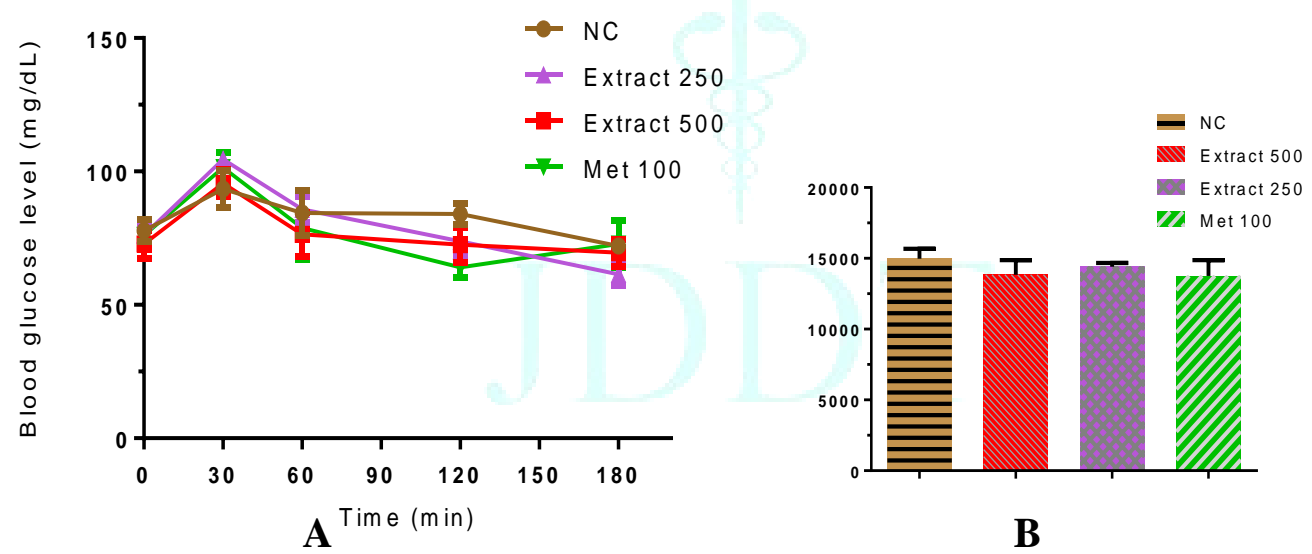

B

Figure 2: Effects of $C$. adansonii extract on basal glucose

( $\mathrm{A}=$ Blood glucose level vs time, $\mathrm{B}=$ Area under the curve (AUC) of blood glucose)

Blood glucose was measured for $180 \mathrm{~min}$ at different time: $0=0 \mathrm{~min}$, corresponds to the measurement of the basal blood glucose level of the fasted mice and t30; t60; t120; t180 correspond to $30 ; 60 ; 120$ and 180 min after administration of distilled water (NC), extracts 500 and $250 \mathrm{mg} / \mathrm{kg}$ and Met $100 . \mathrm{NC}=$ normoglycemic controls; Met $100=$ metformin $100 \mathrm{mg} / \mathrm{kg}$. The values are expressed in means \pm SEM. $* p<0.05 ; * * p<0.01 ; * * * p<0.001$ compared to NC. $\mathrm{n}=5$. 
Phytochemical screening

Table 1: Phytochemical groups present in extract

\begin{tabular}{|l|c|}
\hline Phytochemical compounds and Reagents & Results \\
\hline Alkaloids identification & + \\
Mayer & + \\
Bouchardat & + \\
\hline Tannins identification & + \\
FeCl $2 \%$ & + \\
\hline Flavonoids identification & \\
$\mathrm{NaOH}$ N/10 & + \\
FeCl & + \\
\hline Saponins identification & + \\
Agitation & - \\
\hline Riebermann-Buchard & + \\
Liqueur de Fehling & + \\
Molish & \\
Keller-Killiani & \\
\hline$+=$ presence - absence & \\
\hline
\end{tabular}

Qualitative phytochemical analysis revealed a presence of flavonoids, tannins, alkaloids, saponosides and sterols. Reducing compounds are in trace (Table 1).

\section{Phenolic compound content in extract}

Total phenols and tannins are determined from Gallic Acid calibration curve; while flavonoids from Rutin calibration curve (Figure 3). The phenolic compounds contained in extract were presented in table 2 .

Table 2: Phenols compounds and total antioxidant capacity content in extract

\begin{tabular}{cccc}
\hline Total Phenols (mg GAE/g) & Tannins (mg GAE/g) & Flavonoids (mg RE/g) & TAC (mgAAE/g) \\
\hline $184.330 \pm 0.289$ & $80.539 \pm 0.577$ & $116.765 \pm 0.766$ & $602.667 \pm 4.807$ \\
\hline
\end{tabular}

Flavonoids were highly in C. adansonii leaves than tannins: $63.35 \%$ vs $43.69 \%$ of total phenolic compounds (Table 2).

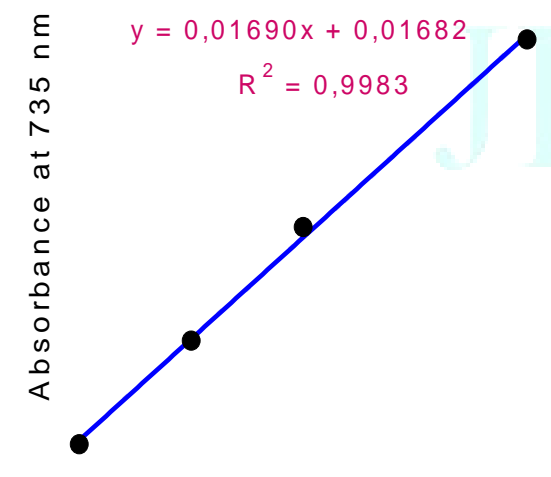

Gallic Acid concentrations $(\mu \mathrm{g} / \mathrm{mL})$ A

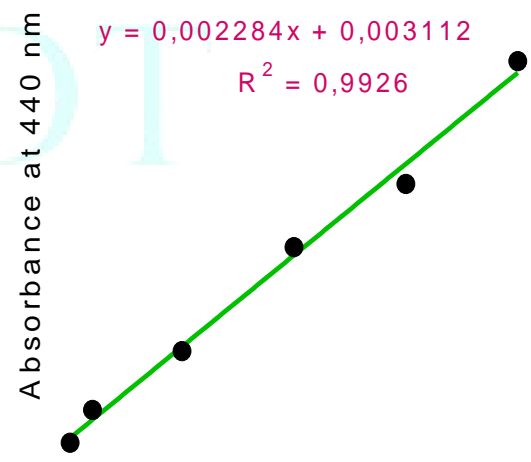

Rutin concentrations $(\mu \mathrm{g} / \mathrm{mL})$

B

Figure 3: Total phenols and flavonoids determination

$\mathrm{A}=$ Gallic Acid calibration curve for total phenols and tannins determination. $\mathrm{B}=$ Rutin calibration curve for flavonoids determination. Values are expressed in means \pm SEM. $; n=3$.

\section{In vitro antioxidant activities of $C$. adansonii leaves}

\section{Total antioxidant capacity}

When increasing concentration of standard, the antioxidant capacity increases positively and is correlated with increasing of absorbance (Figure 4). The TAC value indicates in table 2 represent all antioxidant compounds present in the extract as equivalence of ascorbic acid which act in hydrophilic and lipophilic part. 


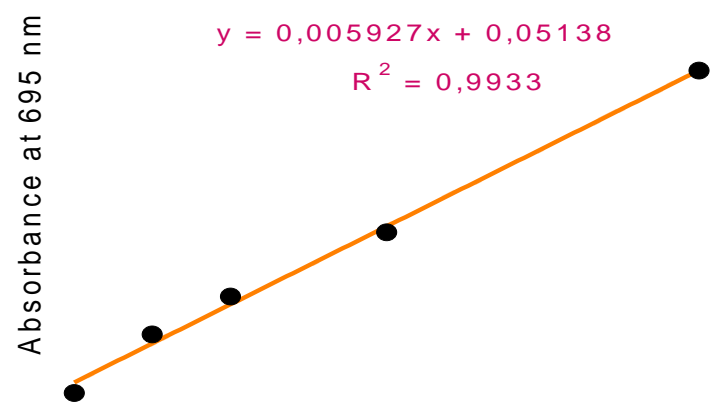

Concentrations of Ascorbic Acid $(\mu \mathrm{g} / \mathrm{mL})$

Figure 4: Ascorbic Acid calibration curve for TAC determination. Values are expressed in means \pm SEM. ; $n=3$.

\section{Reducing power}

The absorbance of extract and controls increase dose-depending and indicate an increase of reducing power. However, the absorbance of the extract is lower than that of controls (BHT and AA) (Figure 5).

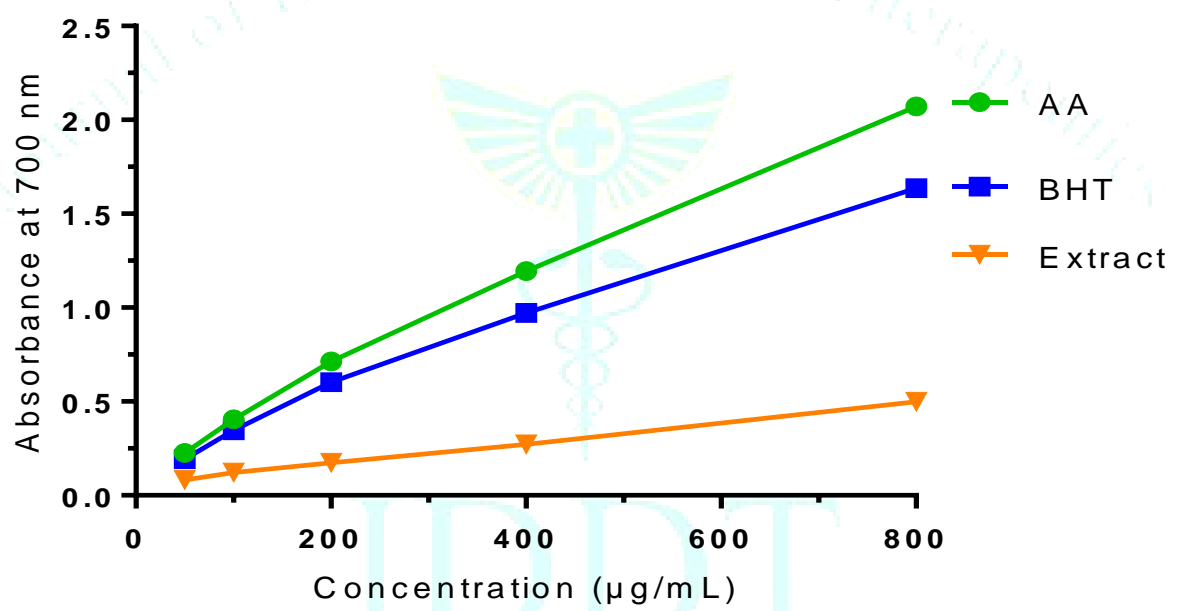

Figure 5: Reducing power of extract compared to BHT and AA.

BHT $=$ Butylated hydroxyl Toluene $. \mathrm{AA}=$ Ascorbic Acid Values are expressed in means \pm SEM. ; $\mathrm{n}=3$.

\section{AAPH free radical scavenging}

C. adansonii delays dose-depending the red blood cells hemolysis by scavenging the free radicals generated by AAPH. Inhibition of hemolysis results in a decrease in absorbance. Therefore, extract showed a higher activity than ascorbic acid (AA) used as reference drug (Figure 6). The inhibitory concentration $50 \%$ of extract was presented in table 3.

The table 3 showed that extract inhibitory concentration $50 \%$ is lower than that of AA. This means that a small concentration of extract would achieve the same levels of free radical scavenging given by AA.

Table 3: Concentration inhibiting 50\% AAPH free radical and Ferrozine- $\mathrm{Fe}^{2+}$ complex

\begin{tabular}{lccc}
\hline$*^{*} \mathrm{C}_{50}(\mu \mathrm{g} / \mathrm{mL})$ & Extract & Ascorbic Acid & EDTA \\
\hline AAPH free radical scavenging & $\mathbf{1 1 0} \pm \mathbf{2 . 7 6 4}$ & $\mathbf{1 7 0} \pm \mathbf{3 . 0 2 1}$ & - \\
\hline $\mathrm{Fe}^{2+}$ chelating & $\mathbf{1 6 2} \pm \mathbf{1 . 6 8 4}$ & - & $\mathbf{2 2 7} \pm 2.043$ \\
\hline
\end{tabular}

${ }^{*} \mathrm{IC}_{50}=$ Inhibitory concentration $50 \%$ 


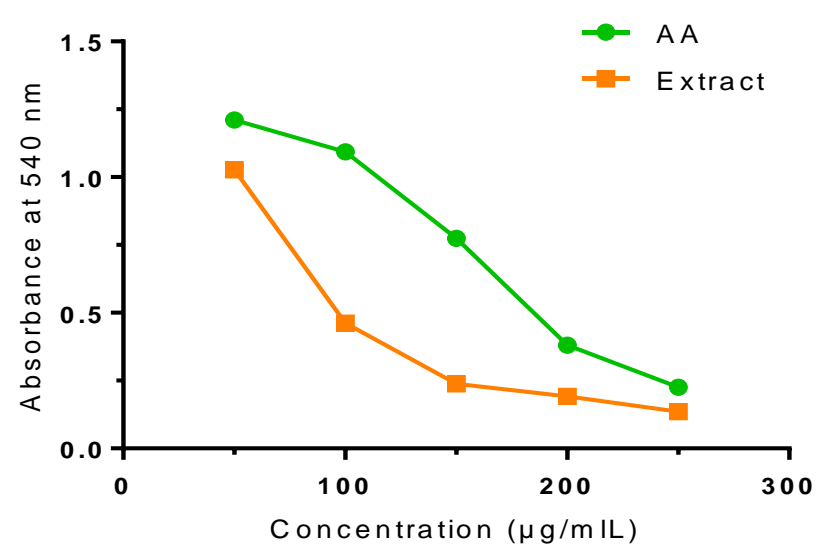

Figure 6: AAPH free radical scavenging activity of extract compared to ascorbic acid (AA)

Values are expressed in means \pm SEM. $; \mathrm{n}=3$.

\section{$\mathrm{Fe}^{2+}$ chelating activity}

Inhibition of Ferrozine-Fe ${ }^{2+}$ complex formation results in a decrease in absorbance. As the concentration increases, the absorbance of extract and EDTA decrease. The absorbances of the extract were lower than that of EDTA and therefore indicate a higher activity of the extract (Figure 7). The extract $\mathrm{IC}_{50}$ confirmed that significant decreased absorbance (Table 4).

Table 4: Concentration inhibiting 50\% AAPH free radical and Ferrozine- $\mathrm{Fe}^{2+}$ complex

\begin{tabular}{lccc}
\hline${ }^{*} \mathrm{IC}_{\mathbf{5 0}}(\mu \mathrm{g} / \mathrm{mL})$ & Extract & Ascorbic Acid & EDTA \\
\hline AAPH free radical scavenging & $110 \pm 2.764$ & $\mathbf{1 7 0} \pm 3.021$ & - \\
\hline $\mathrm{Fe}^{2+}$ chelating & $162 \pm 1.684$ & - & $227 \pm 2.043$
\end{tabular}

*IC $50=$ Inhibitory concentration $50 \%$

Extract $\mathrm{IC}_{50}<$ EDTA IC 50 , that mean the chelating $\mathrm{Fe}^{2+}$ compounds are highly present in the extract when compared to EDTA (Table 4).

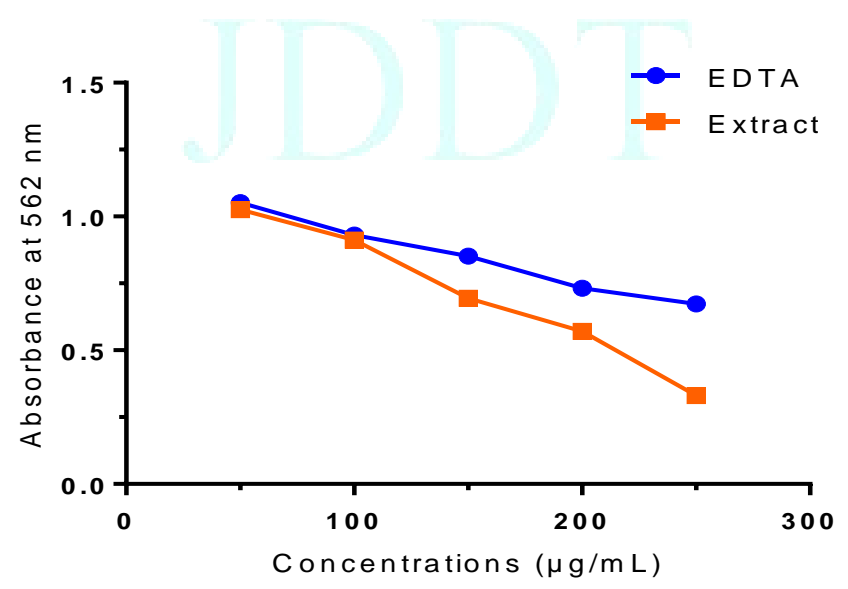

Figure 7: $\mathrm{Fe}^{2+}$ chelating activity of extract compared to EDTA EDTA $=$ ethylenediamineteraacetic acid. Values are expressed in means $\pm \mathrm{SEM} ; \mathrm{n}=3$ 


\section{DISCUSSION}

The ethnobotanical survey conducted among traditional healers of Lome city (Togo) made it possible to select from the list of plants used in the treatment of diabetes, Crateva adansonii. This plant has been evaluated in this study for its antihyperglycemic and antioxidant properties.

Oral hyperglycemia on fasting mice resulted in a significant $(p<0.001)$ increase in blood glucose. Absorbed glucose passed into the general circulation and raised blood glucose; which explains the peak observed at time $t=30 \mathrm{~min}$. Under the action of insulin, the cells responsible for capturing glucose have been sensitized to use and store it as glycogen in the liver mainly [16]. These mechanisms explain the gradual decrease in blood glucose levels until homeostasis is reached around $180^{\text {th }} \mathrm{min}$.

Administration of the hydroalcoholic extract of $C$. adansonii leaves at doses of $250 \mathrm{mg} / \mathrm{kg}$ and $500 \mathrm{mg} / \mathrm{kg}$ body weight prior to on mice OGTT prevented the increase in blood glucose. Only the extract at the dose of $500 \mathrm{mg} / \mathrm{kg}$ cause a significant decrease in mice blood glucose during the 180 $\min (p<0.001$ at $30 \mathrm{~min})$. This action of extract $500 \mathrm{mg} / \mathrm{kg}$ was more important than that of metformin used as a reference. The glucose available in the blood per unit of time determined by AUC confirmed this reduction in blood glucose by the extract. This demonstrates the presence in the extract of antihyperglycaemic compounds that could have resulted in a more marked biological effect at a dose of $500 \mathrm{mg} / \mathrm{kg}$. The extract would have acted thus by delaying or blocking the intestinal absorption of glucose or by sensitizing peripheral tissues to capture glucose or store it primarily as glycogen $[16,17]$.

The two doses of tested extract did not result in a significant decrease in mice basal blood glucose over the $180 \mathrm{~min}$. This suggested that the leaf of $C$. adansonii extract does not directly affect insulin secretion. The action of $C$. adansonii extract $500 \mathrm{mg} / \mathrm{kg}$ is then similar to that of metformin which has an antihyperglycaemic effect, but no hypoglycaemic power (not act on the basal blood glucose). Indeed, metformin is a molecule belonging to biguanid class, which decreases gastrointestinal carbohydrates absorption and inhibits hepatic neo-glucogenesis by activating an intracellular route via AMP-activated protein kinase (AMPK). Metformin also increases peripheral tissues sensitivity to insulin and the uptake of glucose; it does not induce an increase in insulin secretion [18]. The administration of the extract $500 \mathrm{mg} / \mathrm{kg}$ may therefore make it possible to avoid postprandial hyperglycemia in diabetics.

The antihyperglycaemic activity of $C$. andansonii extract is believed to be active in certain phytochemical compounds. Qualitative and quantitative phytochemical analyzes revealed a high presence of flavonoids and tannins. These two polyphenolic compounds would have acted alone or in synergy with other compounds to give the observed antihyperglycaemic effect [19,20].

Furthermore, oxidative stress is an important factor in the onset of diabetes. It leads to the production of free radicals that induce membrane lipids peroxidation and cause damage to tissues and DNA. Reactive oxygen species (ROS) production mainly depends on two factors: mitochondrial oxidative phosphorylation and NADPH oxidase system [21,22]. Mitochondria are indeed the main endogenous source of ROS and can use 95\% available oxygen to produce ATP. About oxygen $2 \%$ enters the electron transport chain; then it is oxidized to superoxide $\left(\mathrm{O}^{2-}\right)$ and hydrogen peroxide $\left(\mathrm{H}_{2} \mathrm{O}_{2}\right)$. In diabetes, the decoupling of mitochondrial electron transport leads to excessive production of superoxide that can stimulate several abnormal biochemical metabolic pathways and increase the production of nitric oxide (NO) resulting in DNA damage $[9,22,23]$. As a result, we have vascular endothelium dysfunction which contributes to the development of cardiovascular disease [24]. The NADPH oxidase system can also generate ROS and catalyze molecular oxygen to produce $\mathrm{O}^{2-}$ and/or $\mathrm{H}_{2} \mathrm{O}_{2}$ by accepting electrons from NADPH and transporting them to molecular oxygen. Antioxidant administration can therefore reduce the oxidative stress and excessive production of NO caused by hyperglycemia. The antioxidant capacity and the reducing power of the plant extract can help to reduce membranes lipids peroxidation and ROS regeneration by the NADPH oxidase system. Otherwise, the antioxidant and reducing power of the extract can be explained by the presence of flavonoids and tannins that interact directly with activated oxygen species to inhibit the formation of free radicals [25]. The total antioxidant compounds present in extract highlight by TAC essay, would have acted in the hydrophilic and lipophilic part. This quantification showed that the leaf extract of $C$. adansonii is rich in antioxidant compounds and can be used to prevent or delay diabetes complications by reducing ROS generated by glucose oxidation.

\section{CONCLUSION}

In vivo evaluation of $C$. adansonii ssp. andansonii leaves extract on oral glucose tolerance and basal blood glucose in mice showed that the plant had an antihyperglycaemic effect and can be used to reduce hyperglycemia during diabetes. The plant extract at a dose of $500 \mathrm{mg} / \mathrm{kg}$ body weight significantly reduced the blood glucose level without lowering basal glucose level. Phytochemical screening revealed a high presence of phenolic compounds such as flavonoids and tannins that could be responsible for the observed antihyperglycaemic activity. These phytochemicals compounds would have acted alone or in synergy. In addition, the extract of the plant has an antioxidant and reducing power and can be used for this purpose in the treatment of diabetes complications related to oxidative stress.

The finding showed that $C$. adansonii ssp. andansonii leaves can be used in the treatment of non-insulin-depending diabetes and its complications. This justifies the use of the leaves of the plant in traditional medicine. However, further studies are needed to elucidate the mechanisms of action of active compounds, to evaluate the toxicity and then to standardize the doses of extract to be administered in order to produce traditionally improve drugs.

\section{CONFLICT OF INTEREST}

The authors declare that they have no competing interests.

\section{REFERENCES}

1. American Diabetes Association, Classification and diagnosis of diabetes: Standards of Medical Care in Diabetes, Diabetes care, 2018; 41(1): S13-S27. https://doi.org/10.2337/dc18-S002

2. International Diabetes Federation, IDF Diabetes Atlas - 8th Edition, 2017. https://diabetesatlas.org/

3. Gitte TA, Kare MA, Deshmukh AM, Ethno-medicinal studies on barks of some medicinal plants in Marathwada (M.S.), India-I. Recent Res Sci Technol, 2012; 4(10): 8-10. https://www.updatepublishing.com/journal/index.php/rrst/ article/view/968

4. Akanji MA, Salau AK, Yakubu MT, Safety evaluation of aqueous extracts of Crateva andansonii Leaves on selected tissues of rats, Fountain Journal of Natural applied Sciences, 2013; 2(1): 17-28.

https://www.researchgate.net/publication/262789589 
5. Zingue S, Cisilotto J, Tueche AB, Bishayee A, Mefegue FA, Sandjo LP, Magne NCB, Winter E, Michel T, Ndinteh DT, Awounfack CF, Silihe KK, Melachio Tanekou TT, CreczynskiPasa TB, Njamen D, Crateva adansonii DC, an Afri-can ethnomedicinal plant, exerts cytotoxicity in vitro and prevents experimental mammary tumorigenesis in vivo, J Ethnopharmacol, 2016; 190: 183-199. https://doi.org/10.1016/j.jep.2016.06.004

6. Adjagba M, Awede B, Osseni R, Hountondji C, Dougnon G, Lagnika L, Darboux R, Laleye A, Antihypertensive effect of extracts from Crateva adansonii DC.ssp. adansonii in the Wistar rats, Int. J. Biol. Chem. Sci., 2017; 11(6): 2604-2615. DOI : https://dx.doi.org/10.4314/ijbcs.v11i6.5

7. Harbone JB. Phytochemical methods, Eds. News York: Chapman and hall; 1973. P. 354. D0l: 10.1007/978-94-0095921-7

8. Chhabra SC, Uiso FC, Mshiu EN, Phytochemical screening of tanzanian medicinal plants, Journal of Ethnopharmacology, 1984; 11(2): 157-179. DO: $10.1016 / 0378-8741(84) 90037-0$

9. Lawson-Evi P, Bakoma B, Titrikou AH, Eklu-gadegbéku K, Aklikokou K, Gbeassor M. Phytochemical screening, antioxidant and hypoglycemic activity of Coccoloba uvifera leaves and Waltheria indica roots extracts, Int J Pharm Pharm Sci, 2015; 279-283. https://innovareacademics.in/journals/index.php/ijpps/artic le/view/5523.

10. Maksimovic Z, Malencic D, Kovacevic N, Polyphenol contents and antioxidant activity of Maydis stigma extracts, Bioresour Technol., 2005, 96(8): 873-877. DOI: $10.1016 /$ j.biortech.2004.09.006

11. Mimica-Dukic N, Investigation on secondary biomolecules in some Mentha-species; Thesis, University of Novi Sad, 1992. P. 150.

12. Prieto $P$, Pineda $M$, Anguilar $M$, Spectrophotometric quantitation of antioxidant capacity through the formation of a Phosphomolybdenum Complex: Specific application to the determination of Vitamin E, Anal Biochem, 1999; 269(2): 337341. https://doi.org/10.1006/abio.1999.4019

13. Oyaizu M, Studies on products of browning reactions: antioxidative activities of products of browning reaction prepared from glucosamine, Jpn J Nutr, 1986; 44(6): 307-315. https://doi.org/10.5264/eiyogakuzashi.44.307

14. Bakoma B, Eklu-Gadegbeku K, Berké B, Diallo A, Agbonon A, Aklikokou $\mathrm{K}$, et al, Total phenolic content, antioxidant activity and in vitro inhibitory potential against key enzymes relevant for hyperglycemia of Bridelia ferruginea extracts, Res J $\begin{array}{llll}\text { Phytochem, 2012; 6(4): 120-126. DOI: } & \end{array}$ 10.3923/rjphyto.2012.120.126
15. Wang $\mathrm{T}$, Jonsdottir $\mathrm{R}$, Olafsdóttir $\mathrm{G}$, Total phenolic compounds, radical scavenging and metal chelation of extracts from Icelandic seaweeds, Food Chem., 2009; 116(1): 240-248. DOI : 10.1016/j.foodchem.2009.02.041

16. Mingueneau M, Chaix A, Scotti N, Chaix J, Reynders A, Hammond C, Thimonier J, Hands-on experiments on glycemia regulation and type 1 diabetes, Adv Physiol Educ, 2015; 39: 232-239. Doi:10.1152/advan.00047.2015.

17. Vitoriano ADS, Malta A, Barrena HC, Furlan MMDP, Bazotte RB, Gazola VG, Blood Glucose Regulation during Fasting in Rats under Food Restriction since Birth, Braz. Arch. Biol. Technol., 2011; 54(1): 67-72. DOI: 10.1590/S151689132011000100009.

18. Kim JD, Park KG, Lee YS, Park YY, Kim DK, Nedumaran B, Jang WG, Cho WJ, Ha J, Lee IK, Lee CH, Choi HS, Metformin Inhibits Hepatic Gluconeogenesis Through AMP-Activated Protein Kinase-Dependent Regulation of the Orphan Nuclear Receptor SHP, Diabetes, 2008; 57(2): 306-314. https://doi.org/10.2337/db07-0381

19. Suba V, Murugesan T, Bhaskara RR, Lopamudra G, Pal M, Subhash CM, Saha BP, Antidiabetic potential of Barheria lupulina extractin rats, Fitoterapia, 2004; 75(1): 1-4. https://doi.org/10.1016/S0367-326X(03)00163-1

20. Andrade-Cetto A, Mexican plants traditionally used from the treatment of type 2 diabetes, Advances in Obesity-Diabetes research at UNAM, $2010 ; 12: 191-200$.

21. Golden TR, Melov S, Mitochondrial DNA mutations, oxidative stress, and aging, Mechanisms of Ageing and Development, 2001; 122(14): 1577-1589. https://doi.org/10.1016/S00476374(01)00288-3

22. Li JM, Shah AM, ROS generation by nonphagocytic NADPH oxidase: potential relevance in diabetic nephropathy, Journal of the American Society of Nephrology, 2003; 14(3): S221S226.

DOI: https://doi.org/10.1097/01.ASN.0000077406.67663.E7

23. Goldstein IM, Ostwald P, Roth S, Nitric oxyde: a review of its role in retinal function and disease, Vision Research, 1996; 36(18): 2979-94. https://doi.org/10.1016/0042-6989(96)00017-X

24. Ceriello A, Postprandial hyperglycemia and diabetes complications, Diabetes, 2005; 54(1) : 1-7. https://doi.org/10.2337/diabetes.54.1.1

25. Ibrahim IF, Nadia E and KR W, In vitro antioxidant activities, total flavonoid, phenolic and carotenoid content from various extracts of four species asteraceae herb, International Journal of Pharmacy and Pharmaceutical Sciences, 2015; 7(4): 192197.

https://innovareacademics.in/journals/index.php/ijpps/artic le/view/4626 